\title{
PROFILE OF A RESEARCH PROJECT: THE MEDAL PUBLICATIONS OF THE SOUTH AFRICAN NATIONAL MUSEUM OF MILITARY HISTORY
}

Dr S. Monick*

\section{INTRODUCTION}

The following particle embodies an analysis of the following four publications, relating to the South African award structure:

(i) Fforde, J.P.I. \& Monick, S. A guide to South African orders, decorations and medals and their ribbons 1896-1985. Johannesburg: South African National Museum of Military History, 1986.

(ii) Monick, S. South African military awards 1912-1987. Johannesburg: South African National Museum of Military History, 1988.

(iii) Monick, S. Awards of the South African uniformed public services 1922-1987. Johannesburg: South African National Museum of Military History, 1988.

(iv) Monick, S. South African civil awards 1910-1990. Pending publication by the South African National Museum of Military History in January 1991

The term "analysis", as opposed to "review", merits considerable emphasis. For it is, of course, impossible for an author to furnish an objective appraisal of his/her own works. Rather, the central motive underlying this article is to provide the reader with a profile of a research project undertaken by the South African National Museum of Military History. The publications cited above absorb and disseminate the products of that research, which may be defined as a structured presentation of the evolution and development of the South African award structure; including an in-depth analysis of the central themes or characteristics of this pantheon. ${ }^{1}$

\section{MOTIVATION}

The Museum had several principal objectives in undertaking this project, and disseminating its results in published form. First, the books functioned as catalogues to the displayed awards. The orders, decorations and medals included within the above quoted works have all been displayed, in a successive series of exhibitions to commemorate special events of South African interest. Thus, the book South African Military Awards 1912-1987 coincided with the mounting of an exhibition devoted to this theme, in 1988, to mark the 75th anniversary of the Citizen Force. The publication, Awards of the South African Uniformed Public Services 1922-1987 appeared in the same year, and commemorated the 75th anniversary of the South African Police; coinciding with a display of awards detailed in the book. In 1990 the display of South African civil awards, spanning the period 1910-1990, commemorated South African Museum day. The three publications written by Dr S Monick (curator of Medals and Numismatics at the SA National Museum of Military History) thus serve as external frames of reference for these exhibitions. It is universally acknowledged that a central function of a Museum is the accurate documentation of its exhibits.

Second, the project exemplifies the Museum's educative function. National awards are a highly significant and graphic index of the nation's cultural-political-social development. This facet is especially germane to the South African experience. With regard to the political aspect, for example, a landmark in South Africa's development was the institution of the Republic in 1961. This cessation of its membership of the British Commonwealth exercised profound repercussions upon the national award structure. The process is especially evident in the awards of the South African Police, which, in 1963, instituted a totally new series of awards (the Cross for Bravery, Star for Merit and Star for Distinguished Service) clearly motivated by the severance with the British traditions appertaining to the imperial award structure. Within the strictly military context, however, the impact of major political developments upon the award structure had dramatically expressed itself a decade earlier. In 1952 there appeared, for the first time, a series of 10 distinctly South African awards, germane to the armed forces; ie Van Riebeeck Decoration, Van Riebeeck Medal, Star of South Africa, Honoris Crux, John Chard Medal, John 
Chard Decoration, Castle of Good Hope Decoration, Louw Wepener Decoration, Union Medal and Southern Cross Medal. These decorations and medals clearly embodied a heavily national orientation of the medals pantheon. The impact of this national dimension is exemplified in the nomenclature of several of these awards; viz the Van Riebeeck Decoration, Van Riebeeck Medal, Castle of Good Hope Decoration, Louw Wepener Decoration. Similarly, the Honoris Crux Decoration represents the reincarnation of an envisaged order, the Order of the Golden Eagle, mooted by the South African Republic (the Transvaal) in 1894. [Information relating to this curious aspect of the Honoris Crux (1952) is contained in the following source: Radburn, A. From Golden Eagle to Cross of Honour. Journal of the Military Medal Society of South Africa, No. 29, August 1987, pp. 21-24.] The institution of the Union Medal embodies the disassociation with the pattern of British long service and good conduct/meritorious service awards, which had been extended to South Africa (ie the Efficiency Decoration (ED), Efficiency Medal, and Medal for Long Service and Good Conduct (Military), all three of which had been instituted in 1939 . [Within this context, it is of interest to note that the long service and good conduct/meritorious service awards of the Citizen Force, instituted in 1952, commemorate the gallantry of a British officer, John Rouse Merriott Chard, who was awarded the Victoria Cross (VC) at Rorke's Drift (22/23 January 1879), in the course of the Zulu War. The association of the Citizen Force long service and good conduct medals with the British military tradition is an acknowledgement of that Force's heritage being rooted in the Victorian military tradition.]

The post-republic period was characterised by the invigoration and development of the South African military tradition; viz the Commando organisation. This re-assertion of the non-British dimension of South African military history attained expression in a series of long service and good conduct/meritorious service awards applicable to the Commandos' viz the De Wet Decoration (1965), Danie Theron Medal (1970) and Jack Hindon Medal (1970) (the designations of these three awards commemorating the memory of distinguished individuals who served the Republican forces during the Anglo-Boer War of 1899-1902).

It is strongly felt that this political-cultural dimension of the nation's award structure strongly merited exploration and detailed research by the
South African National Museum of Military History. The educative function of museums is universally acknowledged as being one of central importance within the community which it serves. It was deemed to be especially apposite that the South African National Museum of Military History pursued this field of research, for two principal reasons.

First, it is the only national military history museum within South Africa, and thus bears a special responsibility in this specific educational project, bearing upon the cultural dimension of the nation's military history. Second, the museum possesses the largest holding of South African awards in Africa (and, indeed, probably in the world). The acquisition of every specimen of South African awards has, indeed, formed a systematic programme of the Museum during the past decade. [The Museum's enormous medal collection includes the most comprehensive range of British awards associated with eminent South Africans - mainly contained within groups - and the extensive character of such a collection has prompted the Museum to render it more accessible to researchers and other interested parties by computerising the records of these holdings.]

The third central motivating factor in this research project relates to the interaction between the SA National Museum of Military History and the South African Defence Force. The Museum is ultimately controlled by the Department of National Education. (Hence the importance placed upon its educational functions, referred to above.) Nevertheless, its role as the national military museum ensures a special sensitivity to the historical aspects of the nation's armed forces, of which the medal pantheons of the Union Defence Forces and South African Defence Force form an important part.

An important point should, perhaps, be registered at the outset. It may justifiably be argued that only one phase of the project is strictly related to the Union Defence Forces/South African Defence Force; viz that relating to military awards. Such an approach would contend that research into the awards of the South African uniformed public services and civil awards are not germane to the armed forces. However, this argument ignores the essential universality and indivisibility of the South African award structure. A very obvious case in point is the Order of the Star of South Africa (both in its previous form 
which possessed divisions into Military and NonMilitary Divisions (1977/1978) and in its present structure, which consists of two distinct orders (Order of the Star of South Africa (Military) and Order of the Star of South Africa (Non-Military) (both instituted in 1988). Awards within the former Non-Military Division and present Non-Military order frequently feature senior officers within the Citizen Force and Commandos (ie non-Permanent Force personnel). [This aspect will be expanded upon below.] A further important aspect of the essential indivisibility of South African awards is the provision for certain South African Police awards to be made to military personnel. A case in point is the South African Police Star for Outstanding Service. (The Museum has been most privileged to receive the medal group of the former Surgeon General, Lt Gen N.J. Niewoudt, during the end of 1990. His most impressive group includes the South African Police Star for Outstanding Service.) Moreover, the problems, inconsistencies and lack of clear documentation which have characterised non-military awards to such a great extent (especially the uniformed public services) [cf below] may serve as an important guide with regard to the future structuring of South African military awards.

\section{BACKGROUND TO PROJECT: THE CREATION OF A STRUCTURED APPROACH}

The forthcoming publication, South African Civil Awards 1910-1990 completes the series of publications devoted to South African awards which commenced in 1986, a point to which the Director of the SA National Museum of Military History, Maj Gen P. Pretorius, SD, SM, refers in his illuminating foreword to the work. In 1986, the work by J.P.I. Fforde and S. Monick, entitled South African orders, decorations and medals and their ribbons 1896-1985 was published. The book was unique in so far as it was preponderantly orientated towards ribbons; and, indeed, included the very first coloured ribbon chart ever produced in South Africa, reproducing every ribbon of South African awards instituted during the period 1896-1985 (ie up to the date of publication). (The work also included the ribbons and details of awards of the South West African Police.) The book formed a milestone in another, extremely important respect. Prior to the research being undertaken, there had been no historical frame of reference, so to speak, for South African awards. Certainly, several papers had been published relating to isolated, specialised facets of South African awards [cf bibliography appended to this article.] However, there was no structured guide to the overall development of the South African medal pantheon. The archival resources of the SA National Museum of Military History - with specific reference to South African awards - was a dramatic illustration of this state of affairs. The Museum's archives undoubtedly contains a most comprehensive source of primary material (principally in the form of Government Gazettes) relating to South African awards; and is probably unrivalled in the entire archival resources of the country. Virtually every award instituted since 1910 is encapsulated within its specific file (to which reference is facilitated via the subject catalogue). To take but two examples, the documentation relating to the Castle of Good Hope Decoration and Louw Wepener Decoration are contained within files classified as 355.134 (68)/Castle of Good Hope Decoration and 335.134 (68)/Louw Wepener Decoration respectively. The Dewey Classification Scheme is adopted in the ordering and numbering of these files. All incoming data (in the form of Government Gazettes, periodical articles, correspondence, etc) are added to the respective files. However, to fully utilise this documentation (ie to order this material within a chronologically structured plan), a sequential series of awards, in date order, would first have to be devised. The research originally undertaken by Col Fforde, in obtaining the precise gazetted descriptions of the ribbons that he was listing and documenting provided this essential basis.

\section{EXTRINSIC AND INTRINSIC FACETS}

The profile of a research project which is discussed in this article may be said to assume both extrinsic and intrinsic forms. The extrinsic form consists of what may be defined as the external structuring of the project; viz the manner in which the publication programme is ordered. The intrinsic facet relates to the material itself, and may be sub-divided into two central aspects:

(i) The methodology employed; viz the peculiar problems which have emerged from the actual processes of research. The methodology adopted has generated certain peculiar problems associated with medal research, which will be explored in detail below.

(ii) The intrinsic character of the material researched; viz the central salient themes 


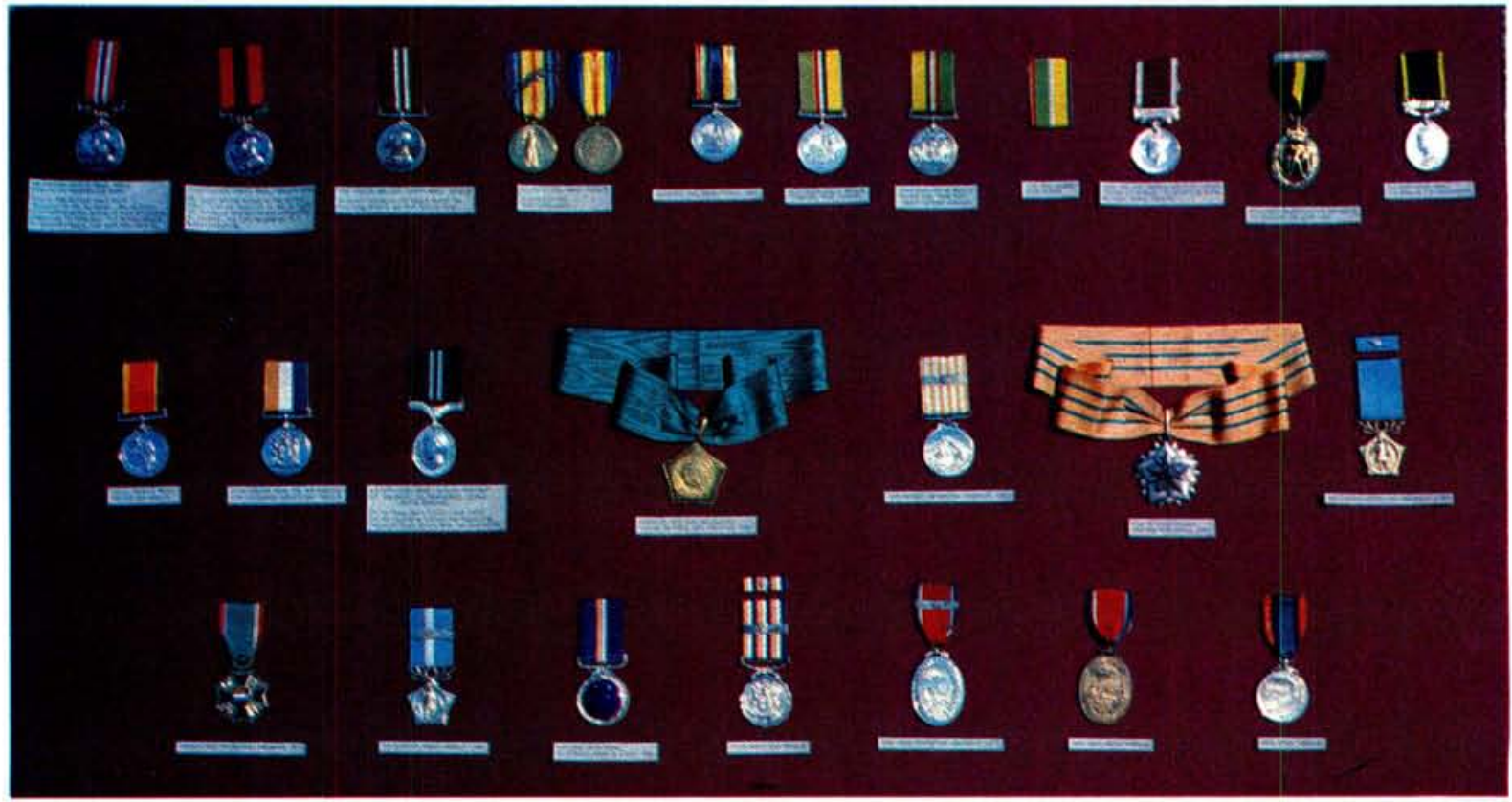

Awards of the SADF 1912-1961 displayed at the SA National Museum of Military history.

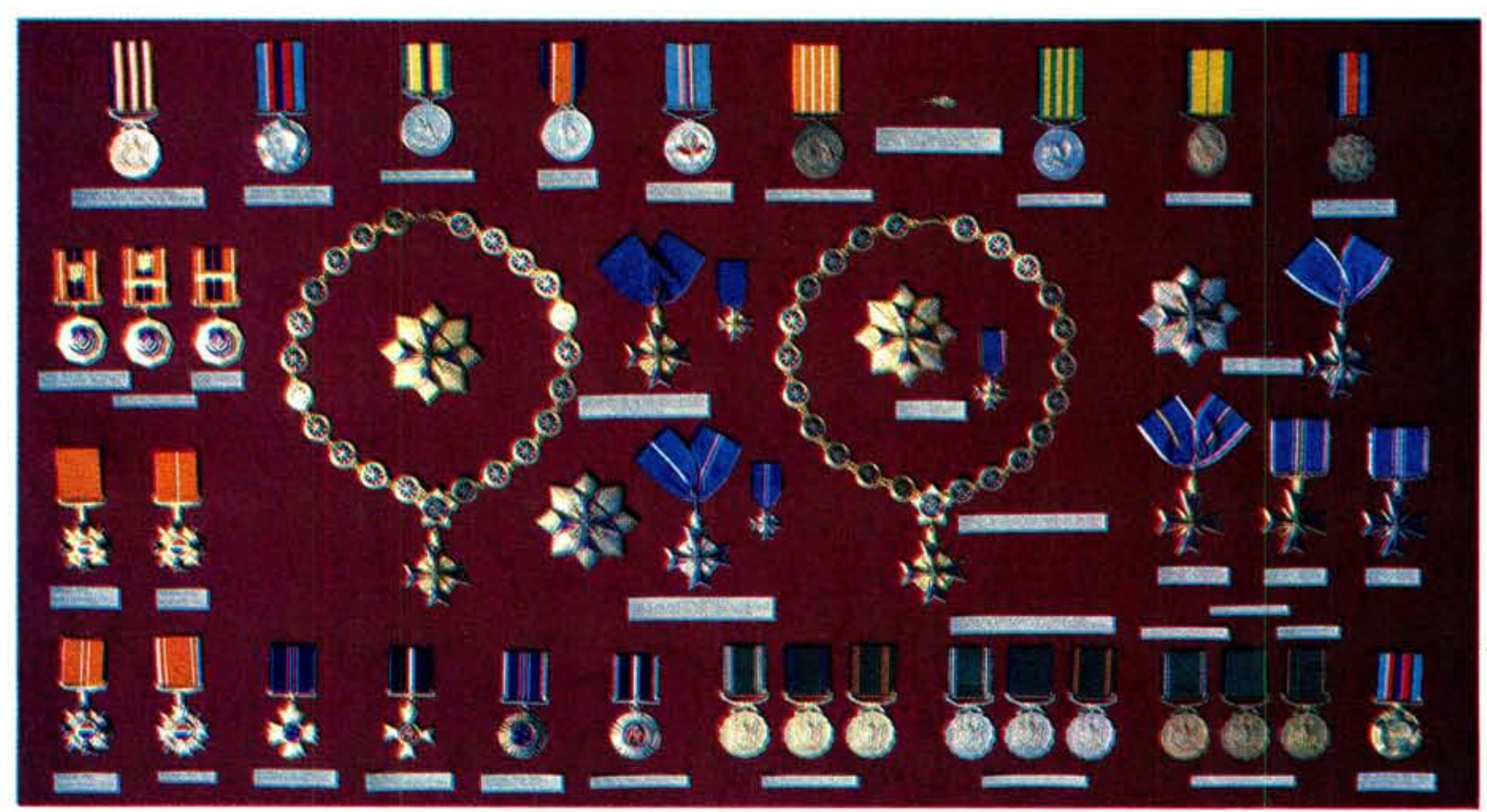

Display of SADF awards 1961-1987 at SA National Museum of Military history.

(Photo's: Eric McPherson) 
cluding the revised word on the obverse, "POLISIEDIENS"; whilst pointing to the inconsistency between the actual wording inscribed on the reverse of the 1932 issue and the gazetted regulation.

In strictly legalistic terms, therefore, the Railways and Harbours Police Long Service and Good Conduct Medal (post 1953), Police Good Service Medal (1932-1951) and variations of the Prisons Good Service Medal (1922) represent unauthorised strikings. It is feasible that the source of such deviations or discrepancies resides in force regulations not being embodied in Government Gazettes. Thus, it is, perhaps, symptomatic of the parochial development of the South African award structure.

(d) Bar: As stated in ASAUPS, No 20 ( $p$ 55), there is very strong evidence to suggest that the wording embossed on the bar of the Railways and Harbours Police Long Service and Good Conduct Medal (1934) underwent a transformation during its 26 year history. Yet no such alteration has been gazetted. The same considerations applies to the Prisons Good Service Medal (1922). There is good reason to believe that the bar underwent a transition in the course of this award's history, and later strikings of the 1922 version may well possess this altered bar. The following considerations lend credence to this assumption:

(i) To reiterate, the bar of the Railways and Harbours Police Long Service and Good Conduct Medal underwent a change which is not reflected in any gazette. It is probable that such a precedent strongly influenced the Prisons Service,

(ii) The Prisons Good Service Medal remained extant for 37 years. It is extremely improbable that, in view of the presence of non-gazetted strikings (cf above), the bar remained unaltered during its entire history.

(iii) The presence of unauthorised strikings of the Prisons Good Service Medal (which probably appeared during the 1950s, prior to the gazetting of the Faithful Service Medal in the Prisons Department) considerably reinforces the supposition of the production of different bars subsequent to that originally produced for the first striking in 1922.

(iv) Eligibility: The Louw Wepener Decoration represents an interesting illustra- tion of a decoration's wide divergence from the conditions of eligibility, as originally gazetted. In its original conception, the award was confined to deeds for which other purely military honours were not normally awarded (cf SAMA, No $15, \mathrm{p} 26$ ). It roughly approximated to the George Cross (GC) in this regard. However, Lt Frederick Zeelie received the award posthumously for sacrificing his life in a completely military operation (SAMA, No 15, p 27). One is justified in regarding the Castle of Good Hope Decoration (CGH) as a more appropriate form of recognition (although the regulation requiring the presence of a senior officer as a witness may well have precluded the award of this decoration). Similarly, the Honoris Crux (1952) would have been a more suitable award, but for the regulation which specifically precludes the posthumous award of this decoration.

\section{PROBLEMS ASSOCIATED WITH THE SOUTH AFRICAN MEDAL PANTHEON}

\section{(i) Lack of clear demarcation between categories of award}

If one examines the South African medal pantheon in depth a curious feature emerges; viz that some awards which are designated as decorations share vital common characteristics with those of orders, and vice versa, in terms of both organisation and insignia. As a case in point one may examine the "Honoris Crux Decoration". Instituted in 1975, this decoration is graded in the following manner (in ascending order of seniority):

- Honoris Crux

- Honoris Crux Silver

- Honoris Crux Gold

- Honoris Crux Diamond

However, what one has in these delineations is the graded ranks that one associates with an order. The introduction of grades of membership becomes a noted characteristic of the emergence of orders of merit, symptomatic of the increasing democratisation of orders. The "South African Prisons Service Cross for Valour" is structured in a similar manner to that of the Honoris Crux Decoration (1975):

- South African Prisons Service Cross for Valour (Diamond) 
- South African Prisons Service Cross for Valour (Ruby)

A further curious feature of this facet relates to insignia. Those of British orders are, invariably, suspended from the neck (the Distinguished Service Order is a notable exception) whilst decorations are, without exception, suspended from breast ribbons. However, within the South African context the following awards, officially categorised as decorations, are, in actual fact, suspended from neck ribbons/chains (ie the practice with regard to British orders):

\section{- Castle of Good Hope Decoration}

- South African Police Cross for Bravery (1963 issue)

- Decoration for Meritorious Service

- National Intelligence Service Decoration for Distinguished Leadership

- South African Railways Police Cross for Valour (1966 issue)

In terms of qualifications for eligibility, the categories of orders and decorations are sometimes reversed. A case in point is the (now obsolete) Decoration for Meritorious Service. The instituting Government Gazette (No 2836, dated 25 September 1970) definitely categorises the award as a decoration. However, the Gazette specifies the following eligibility for the award:

"Whereas it is desirable to take into consideration and to recognise exceptionally distinguished services to the Republic of South Africa."

Such terms of qualification clearly point to the award's association with an order (e.g. the Most Excellent Order of the British Empire. (It is a fundamentally false argument to aver that the Decoration for Meritorious Service is precluded from the category of orders as it has only one class. Several extant British orders share this characteristic; i.e. the Order of the Garter, the Distinguished Service Order, the Order of Merit, the Order of the Companions of Honour, as, indeed, does the South African Police Star for Distinguished Leadership and South African Railways Police Star for Distinguished Leadership. The Decoration for Meritorious Service's association with an order is further reinforced by its neck ribbon. It is feasible that the award's supercession, in 1986, by the Order of Meritorious Service embodies a recognition of these anomalies.

Within this context of distinction between cat- egories of award, it is of interest to note that the (now obsolete) South African Police Star for Distinguished Service is officially categorised as a decoration in the instituting Government Gazette (No 6451, dated 18 May 1979). However, it is difficult to formulate a distinction between this award and the South African Police Star for Distinguished Leadership (now obsolete), which is classified as an order (although the insignia of the latter does include a breast star). Moreover, Clause 4 of the instituting Government Gazette of the South African Police Star for Distinguished Service reserves the decoration for officers of the general staff in the South African Police. This condition clearly separates the award from the British tradition, in so far as it has become a firm tradition within the British award structure that decorations be awarded irrespective of rank (always bearing in mind the allocation of distinct awards for commissioned and non-commissioned ranks). However, it is a convention that the senior ranks of orders tend to be reserved for those holding senior positions in civil and military life. Hence, the problem of the distinction between order and decoration, in this specific instance, is compounded.

A similar difficulty is to be observed in the relationship between the South African Railways Star for Distinguished Leadership and Star for Distinguished Service. The former is officially designated as an order (Government Gazette No 7002 , dated 16 May 1980) and the latter is categorised as a decoration in the same gazette. One observes the same problem as in the South African Police awards of the same nomenclature. The South African Railways Police Star for Distinguished Service is characterised by insignia commonly associated with an order (neck chain and neck ribbon). Moreover, Clause 5 of the instituting Gazette states:

"The decoration may be awarded only to a [sic] officer of the general staff in the South African Railways Police Force who has distinguished himself through meritorious service in promoting the efficiency of the South African Railways Police Force or who has contributed actively to the security of the Republic of South Africa."

As in the case of the South African Police award of the same designation, the restriction of the decoration to the officers of the general staff reinforces the association with an order. The South African Railways Police Star for Distinguished Leadership is similarly reserved for 


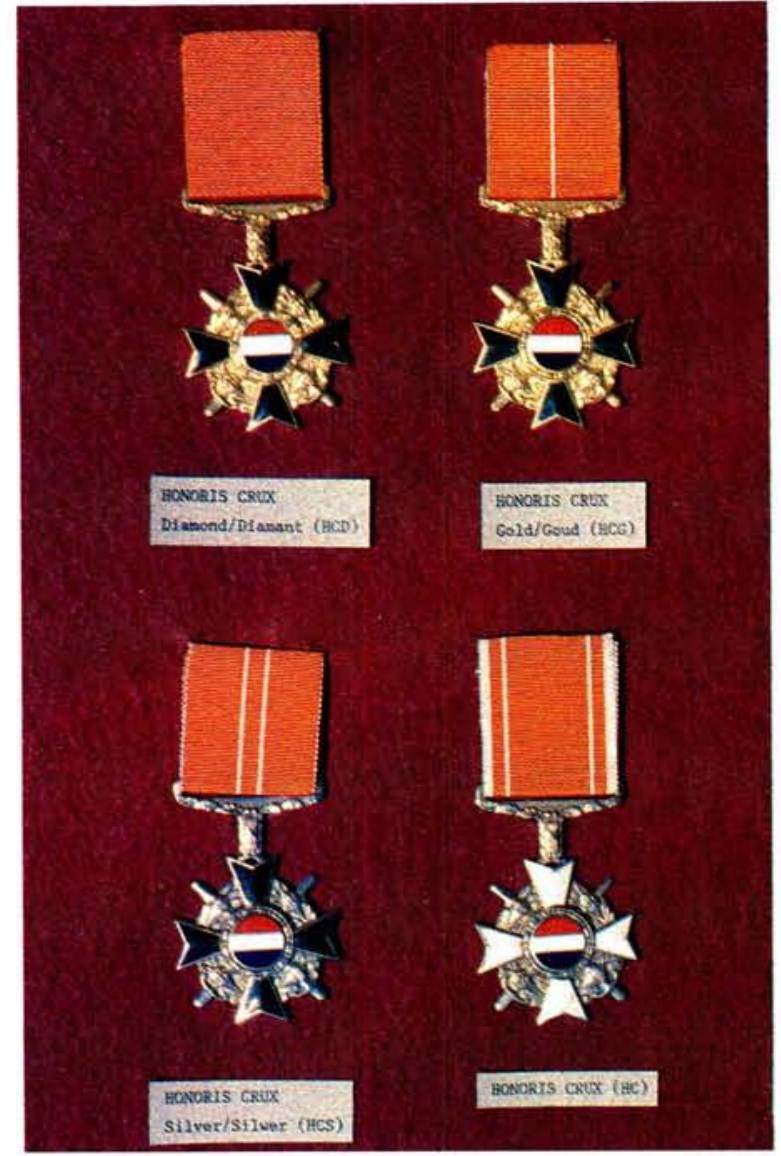

Honoris Crux Decoration (1975)

Top left: Honoris Crux Diamond (HCD)

Top right: Honoris Crux Gold (HCG)

Bottom left: Honoris Crux Silver (HCS)

Bottom right: Honoris Crux (HC).

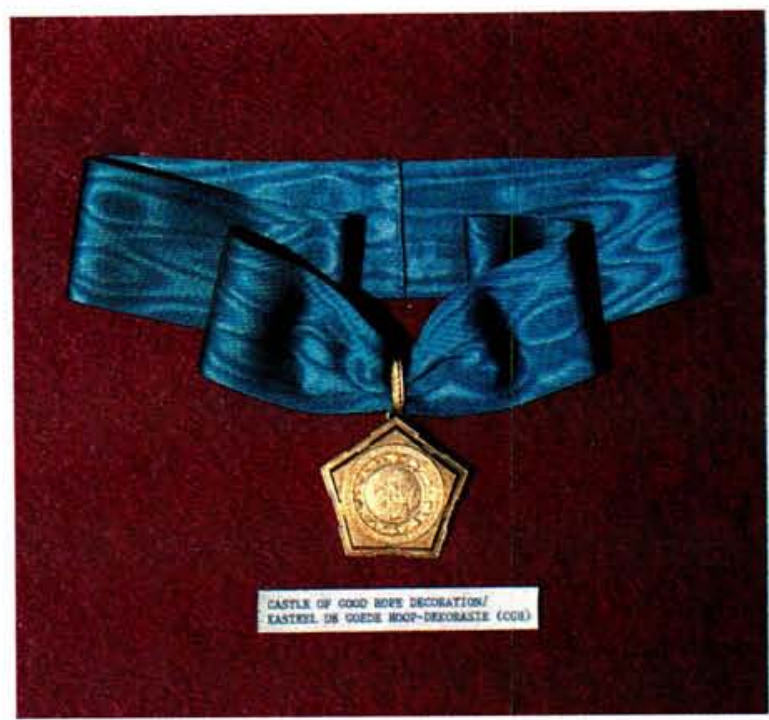

Castle of Good Hope Decoration (CGH).

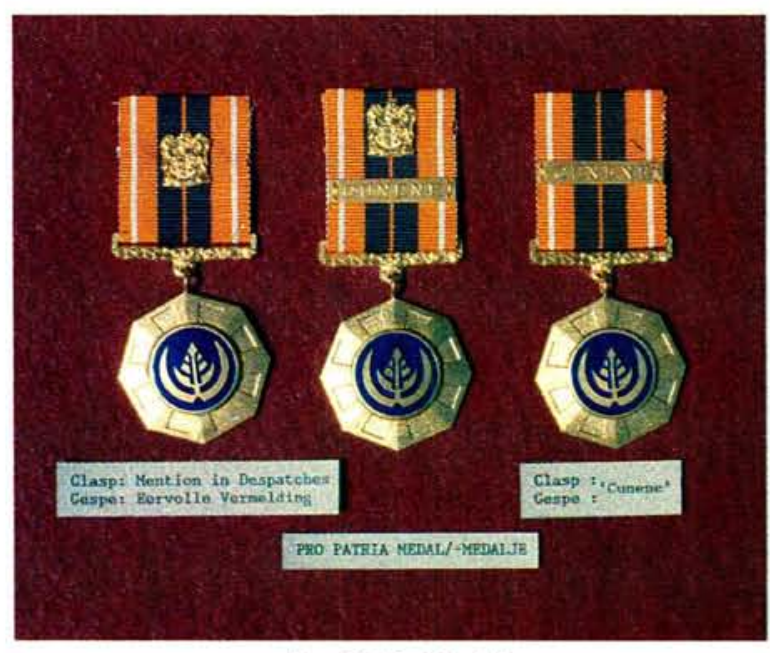

Pro Patria Medal

Left: With mention in despatches emblem Centre: With mention in despatches emblem/Cunene clasp

Right: With Cunene clasp.
(Photo's: Eric McPherson)

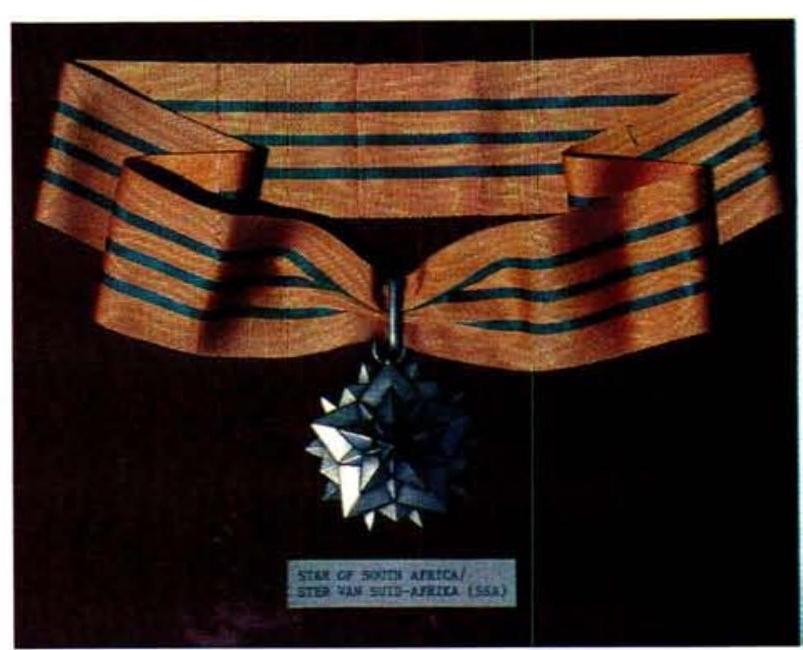

Star of South Africa (SSA)

The predecessor of the order of the star of South Africa. 
senior ranks. The fact that the problems implicit in the relationship between the two South African Police awards are duplicated with regard to the South African Railways Police awards of the same designation, suggests that the latter adopted precedents utilised by the former.

\section{(ii) Lack of stability}

It is undeniable that the South African medal pantheon reveals a high degree of instability, embodied in the consistent abolition of awards. If one adopts the year 1952 as the starting point, the following orders, decorations and medals have been subject to this process:

\section{A. Military awards}

1. Louw Wepener Decoration (1952) Superseded by Honoris Crux Decoration (1975)

2. Star of South Africa (1952)

Superseded by the Order of the Star of South Africa (1975/1977/1978)

3. Van Riebeeck Decoration (1952)

4. Honoris Crux (1952) Superseded by the Honoris Crux Decoration (1975)

5. Van Riebeeck Medal (1952)

6. Southern Cross Medal (1952) Superseded by the Southern Cross Medal (1975)

7. Union Medal (1952)/Permanent Force Good Service Medal (1961)

Superseded by the South African Defence Force Good Service Medal (Gold, Silver, Bronze) (1975)

8. Commandant General's Medal (1965) Superseded by the SADF Champion Shot Medal (1975)

9. Pro Merito Medal (1967) Superseded by the Pro Merito Medal (1975)

10. Commandant General of the South African Defence Force Commendation (1968)

Superseded by the C SADF Commendation Medal (1974)

11. Jack Hindon Medal (1970)

12. Order of the Star of South Africa (1975)

Superseded by the Order as re-constituted in 1978

13. Order of the Star of South Africa (1978) Superseded by
(a) Order of the Star of South Africa (Mili- tary) (1988)
(b) Order of the Star of South Africa (Non- Military) (1988)

\section{B. South African Police Awards}

1. Police Good Service Medal (1923/1932/ 1951)

Superseded by South African Police Medal for Faithful Service (1963)

2. King's Police Medal (1937)

- For Gallantry

- For Distinguished Service

3. Queen's Police Medal (1952)

- For Gallantry

- For Distinguished Service

Note: Items 2-3 above superseded de facto by:

- South African Police Cross for Bravery (1963)

- South African Police Star for Distinguished Service (1963)

4. South African Police Cross for Bravery (1963)

Superseded by award of the same name, divided into three grades, instituted in 1989.

5. South African Police Star for Distinguished Service (1963)

Superseded by South African Police Star for Distinguished Service (1979)

6. South African Police Star for Distinguished Leadership (1979)

7. South African Police Star for Distinguished Service (1979)

8. South African Police Silver Cross for Gallantry (1985)

Superseded by South African Police Cross for Bravery Silver (1989)

\section{South African Railways Police Awards}

1. Railways and Harbours Police Long Service and Good Conduct Medal (1934)

Superseded by Railway Police Good Service Medal (1960)

2. Railway Police Good Service Medal (1960) Superseded by Medal for Faithful Service in the South African Railways Police Force (1966)

3. Star for Merit in the South African Railways Police Force (1966)

Superseded by the Star for Merit in the South African Railways Police Force (1980)

4. Medal for Faithful Service in the South African Railways Police Force (1966)

Superseded by Medal for Faithful Service in the South African Railways Police Force (1980)

5. South African Railways Police Cross for Valour (1966)

Superseded by South African Railways Police Cross for Valour (1980) 
6. Decoration for Distinguished Service in the South African Railways Police Force (1966)

Superseded by

(a) Decoration for Outstanding Service in the South African Railways Police Force (1980) and

(b) South African Railways Police Star for Distinguished Service (1980)

\section{South African Prisons Service Awards}

1. Prisons Good Service Medal (1922) Superseded by Faithful Service Medal in the Prisons Department (1959)

2. Faithful Service Medal in the Prisons Department (1959)

Superseded by Faithful Service Medal, Prisons Department (1965)

3. Faithful Service Medal, Prisons Department (1965)

Superseded by Medal for Faithful Service in the South African Prisons Department (1968)

4. Decoration for Valour in the South African Prisons Service (1968)

5. Medal for Merit in the South African Prisons Service (1968)

6. Medal for Faithful Service in the South African Prisons Service (1968)

Note: Items 4-6 superseded in entirety by series of Prisons Service Awards instituted in 1960; especially:

(i) Decoration for Valour in the South African Prisons Service superseded by Cross for Valour (Diamond) (1980)/ Cross for Valour (Ruby) (1980)

(ii) Medal for Merit in the South African Prisons Service superseded by Star for Merit (1980)/Cross for Merit (1980)/ Medal for Merit - Commissioned Officers (1980)/Medal for Merit - Non-Commissioned Officers (1980)

(iii) Medal for Faithful Service in the South African Prisons Service superseded by South African Prisons Service Medal for Faithful Service (1980)

\section{E. Civil Awards 1910-1988}

1. King's Medal for Bravery (1939)/Queen's Medal for Bravery (1952)

Superseded by Woltemade Decoration (1970)

2. Woltemade Decoration (1970)

Superseded by Woltemade Cross for Bravery (1988)

3. National Intelligence Service Cross for Valour (1981)
Superseded by National Intelligence Service Cross for Valour - Gold \& Silver (1987)

4. National Intelligence Service Medal for Distinguished Service (1981)

Superseded by National Intelligence Service Medal for Distinguished Service Gold, Silver, Bronze (1987)

5. Decoration for Meritorious Service (1970) Superseded by Order for Meritorious Service (1986)

It is apparent that the South African Medal pantheon displays an indisputable restlessness, a facet which exhibits the following noteworthy characteristics:

(i) A number of awards were rendered obsolete within a decade of their institution; i.e.

- Commandant General of the South African Defence Force Commendation

- Pro Merito Medal

- Jack Hindon Medal

- Order of the Star of South Africa

(ii) The situation is confused by the fact that several awards have been succeeded by those bearing identical designations; i.e.

- Southern Cross Medal (1952/1975)

- Pro Merito Medal (1967/1975)

- South African Police Cross for Bravery (1963/1989 - 3rd Grade)

- South African Police Star for Distinguished Service (1963/1979)

- South African Railways Police Cross for Valour (1966/1980)

- Star for Merit in the South African Railways Police Force (1966/1980)

- Medal for Faithful Service in the South African Railways Police Force (1966/ 1980)

The result of such instability is to generate a certain degree of uncertainty regarding the precise status, or weight of prestige, attached to the awards in question. The problem of definition is compounded by inconsistency with regard to post-nominal letters; an inconsistency which is manifested on three levels. First, in relation to the awards of the South African Police and South African Railways Police, where an award is succeeded by one bearing the same nomenclature the post-nominal letters attached to the preceding award are utilised for its successor (i.e. South African Police Star for Distinguished Service; South African Railways Police Cross for Valour (SOO/IF respectively). However, the SADF has adopted a contrasting policy. Thus, the Southern Cross Medal (1952), which pos 
sessed the post-nominal letters "SM", was replaced by the award of the same designation in 1975, but without post-nominal letters. The same policy was adopted with reference to the Pro Merito Medal (PMM), instituted in 1967, and its successor. The privilege of appending postnominal letters necessarily enhances its prestige, and the withdrawal of this prerogative equally implies a dimunition of the award's status. It is necessary to bear in mind that this inconsistent policy viz-a-viz post-nominal letters has been applied to extant awards. Thus, the privilege of appending post-nominal letters to the De Wet Decoration (DWD) and John Chard Decoration (JCD) was withdrawn in terms of Amending Warrants dated 22 June 1977 (published in Government Gazette No 5651, dated 8 July 1977); to be re-introduced in terms of Amending Warrants dated 27 August 1986 (published in Government Gazette No 10494, dated 24 October 1986). [This temporary withdrawal of post-nominal letters was perhaps motivated by the objective of equating the status of these awards with the South African Defence Force Good Service Medal (Silver) for Citizen Force and Commandos. None of the three grades of this latter award confer the privilege of post-nominal letters.]

The second level on which this inconsistent policy with regard to post-nominal letters operates relates to the practice whereby the same letters are applied to succeeding awards of different nomenclature (i.e. the letters "SMO" applied to both the South African Railways Police Decoration of Distinguished Service (1966) and Decoration for Outstanding Service (1980)).

Third, one has the situation where the same post-nominal letters relate to multiple awards, both within the compass of the instituting body and transcending several branches of service. An illustration of the former practice is embodied in the post-nominal letters "CPV", designating both the South African Prisons Service Cross for Valour Diamond and Decoration for Valour. The latter process is exemplified in the letters "SOE", which apply to both the South African and South West African Police Star for Outstanding Service and (until 1983) the South African Railways Police Star for Distinguished Service.

The restless character of the South African medal pantheon is further manifested in the sphere of ribbons. Thus, the ribbons of the Southern Cross Medal (1975), Pro Merito Medal (1975) and South African Defence Force Good
Service Medal (1975) were altered in terms of Warrants dated 27 August 1986 (published in Government Gazette No 10494, dated 24 August 1986).

\section{(iii) The problem of equivalence}

It was stated at the commencement of this section that the dominant characteristic of traditional medal pantheons is that of hierarchy, which facilitates the clear appreciation of the status of a particular award. However, the essentially parochial character of the South African award structure has largely militated against the hierarchical approach by generating multiple arrays of awards within each category. Thus, the armed forces, South African Police, South African Prisons Service and former South African Railways Police all possess gallantry awards which, obviously, occupy the senior positions within their respective orders of precedence. Their positions within a national order of precedence (i.e. their relationship to one another) is thus highly problematical as, within each instituting body, they enjoy an equivalent status) (cf ASAUPS, pp $26-27)$. It is, possibly, this aspect of the national award structure which has impeded the emergence of a revised national order of precedence since 1979.

\section{THE MANAGEMENT OF A MEDAL PANTHEON}

These three major problems implicit in the South African award structure point to certain central determinants which, ideally, should be applied to a medal pantheon:

(a) The need for a clearly defined framework of subordination.

(b) The requirement of stability, ensuring that awards, once instituted, remain firmly anchored in the national structure of honours and awards.

(c) The initial conception of awards (in terms of conditions of eligibility, design, ribbon, etc.) in such a manner that they are, as far as possible, mutually exclusive in terms of category (i.e. order, decoration, campaign medal, etc.).

(d) The emphasis upon universality; i.e. that awards should, as far as possible, be applicable to individuals irrespective of their association with a specific institution. This would contribute to the determinant itemised under (a) above, in so far as one would 
avoid multiple arrays of awards of equal status.

(e) The need for flexibility. This consideration would avoid the common South African practice whereby the regulations stipulate that the award in question be confined to the most senior ranks of a service (i.e. as in the case of: the Order of the Star of South Africa (Military); the South African Police Star for Distinguished Service (1979); the South African Police Star for Distinguished Leadership; the South African Railways Police Star for Distinguished Leadership; South African Railways Police Star for Distinguished Service; South African Prisons Service Star for Excellence; South African Prisons Service Star for Distinction).

Admittedly, it is a generally recognised feature of the British award structure that certain honours (e.g. inclusion within the higher grades of orders, conferring knighthood) are confined to the most senior ranks of the armed and civil services. But, it should be emphasised, this facet represents a traditional usage and not a fixed stipulation. A certain degree of latitude is thus facilitated, permitting recognition, through the award of such honours. to individuals who have rendered exceptional service, and yet do not fall within the ranks of those normally eligible for such forms of recognition. Indeed, it may be feasibly argued that the source of the (justifiably) unreal distinction between the Military and NonMilitary Divisions/Orders of the Star of South Africa is rooted in the restriction of the former to the most senior officers of the Permanent Force.

\section{THE EXTRINSIC FACET}

The initial work by Col Fforde and Dr Monick thus formed the essential foundation of the SA National Museum of Military History's exploration of the South African award structure.

Upon the basis of this original research undertaking, the Museum's research project would be formulated. It was considered that this would assume the following form:

(a) Col Fforde's research would be expanded into a series of three monographs, each devoted to a special branch of the South African award structure; viz. the awards of the armed forces, those of the uniformed public service (South African Police, South West African Police, South African Railways Police, South African Prisons Service); and South African civil awards. Col
Fforde is primarily a ribbon collector (his latest publication, co-authored by Mr Alan Rich, is devoted to the ribbons of Rhodesian awards) and the publication of which he was the prime author was, to reiterate, preponderantly concerned with this sphere of his interest. Only the briefest information was attached to each description of the individual award cited. However, as the relevant Government Gazettes were cited in this publication, the essential documentation, which would form the basis of this further research, was readily available. Thus, the quoted Government Gazettes would, upon close scrutiny, yield the relevant details concerning detailed description of each award, conditions of eligibility, relationship to earlier and succeeding awards, amending regulations etc.

The original publication structured the awards in a strict chronological order. The decision to present three distinct publications, in the manner discussed above, was determined by two central characteristics implicit within the intrinsic character of the South African medal pantheon, which emerged from the research undertaken.

(i) The first was the essentially parochial character of the South African award structure; viz. the institution of awards which are, in the main, confined to a special branch of the armed and civil services.

(ii) The peculiarly restless and unstable character of the nation's award structure; manifested in the continual supersession of former awards and corresponding proliferation of new orders, decorations and medals.

This second characteristic determined the staggered publication of the three monographs over a span of years; as opposed to the creation of a single work divided into the appropriate sections. Had the latter course been adopted, it was feared that a composite book would be rapidly vulnerable to obsolescence, in the light of the instability which characterises the South African award structure, commented upon above. Conversely, additions and amendments to this structure could be absorbed into later publications. Thus, the envisaged publishing programme would permit of a far higher degree of flexibility.

The validity of such an approach would appear to be justified by the publication, South African orders, decorations and medals, by E.G.M. Alexander, G.K.B. Barron and A.J. Bateman (published in 1986). This handsomely produced 
work is now seriously obsolete; and yet the necessity for the consistent revision of the publication - in the light of the continual additions to the South African award structure - is a highly expensive proposition each time such a project is undertaken (which must, of necessity, be on a frequent basis.)

The actual course of events proved such an approach justified, in the following respects:

1. One year after the publication of ASAUPS a new series of South African Police decorations was instituted; the South African Police Cross for Bravery Gold, the South African Police Cross for Bravery Silver and South African Police Cross for Bravery. These awards replaced the former South African Police Cross for Bravery (1963) and South African Police Silver Cross for Gallantry (1985). Moreover, the South West African Police Star for Merit (although officially instituted in 1986) officially made its appearance in 1988, some three weeks prior to the publication of ASAUPS and had to be included within an appendix to that work.

Further, at the end of 1990, when the publication of SACA was approaching finalisation, documentation was received indicating that two new South African Defence Force awards were shortly to be gazetted; viz. the General Service Medal and Southern Africa Medal. These awards were subsequently gazetted in terms of Warrant of 24 May 1989 (but only published in Government Gazette No 12907 , dated 21 December 1990). These awards were gazetted at too late a date to be absorbed within the ribbon guide of SACA, and must now be included in either a separately published appendix to SAMA, or a revised edition to the entire work. The institution of these new medals highlights the problem of endeavouring to encapsulate a constantly evolving and restless award structure in a concrete published form.

It is also noteworthy that, at the end of 1990 , information was received to the effect that a further 10 SADF awards were to be instituted in the near future:

Army Cross

Air Force Cross

Navy Cross

South African Medical Service Cross

Pro Virtute Decoration

Pro Virtute Medal
SADF Good Service Medal (for 40 years service)

Ad Aspera Medal

De Wet Medal

Cadet Corps Shooting Medal

2. Within two years of the appearance of the first work by Col Fforde and Dr Monick, no fewer than five new orders had been instituted:

Order of the Southern Cross (1986)

Order for Meritorious Service (1988)

Order of the Star of South Africa (Military) (1988)

Order of the Star of South Africa (Non-Military) (1986)

Order of Good Hope (1988)

3. By the end of 1988 two new decorations had been instituted; viz. the Woltemade Cross for Bravery (1988) (superseding the Woltemade Decoration for Bravery (1970)) and the President's Decoration for Distinguished Service (1987).

4. In 1990 the latest addition to the South African medal pantheon was instituted; viz. the National Intelligence Service Civil Medal.

The publication of the Museum's research into the South African award structure occurred during a span of four years. To recapitulate, the two books published in the same year (SAMA, ASAUPS) had their dates of publication determined by the need to commemorate important landmarks in the historical calendars of both the Citizen Force and South African Police. However, a lapse of two years occurred before the final book, relating to South African civil awards, was produced. This staggered publishing programme did, however, permit the awards itemised under $2-4$ above to be included.

The constantly evolving structure of the South African medal pantheon also determined the revision of the coloured ribbon guide. To reiterate a point made above, the terms of reference and the scope of $A$ Guide to South African Orders, Decorations and Medals and their ribbons ended in 1985 and, accordingly, the coloured ribbon guide which it included ended at that point. Since that date, the following South African awards have been gazetted:

(a) Order of the Southern Cross (1986)

Same ribbon for both grades.

(b) Order for Meritorious Service (1986)

Same ribbon for both grades. 
(c) Order of Good Hope (1988)

- Class I: Grand Cross (Gold)

- Class II: Grand Officer (Silver)

- Class III: Commander

- Class IV: Officer

- Class V: Member

(d) Woltemade Cross for Bravery - Gold \& Silver (1988)

Same ribbon for both grades.

(e) President's Decoration for Distinguished Service (1987).

(f) Order of the Star of South Africa (Military) (1988)

- Class I: Gold

- Class II: Silver

(g) Order of the Star of South Africa (Non-Military) (1988)

- Class I: Grand Cross

- Class II: Grand Officer

- Class III: Commander

- Class IV: Officer

- Class V: Member

(h) National Intelligence Service Cross for Valour (1987)

- Gold

- Silver

(i) National Intelligence Service Medal for Distinguished Service (1987)

- Gold

- Silver

- Bronze

(j) South African Police Seventy-Fifth Anniversary Commemorative Medal (1988)

(k) South African Police Cross for Bravery (1989)

- South African Police Cross for Bravery (Gold)

- South African Police Cross for Bravery (Silver)

- South African Police Cross for Bravery

One should also note

(I) South West African Police Star for Merit (1986)

In addition, amending Warrants have instituted completely new ribbons for the following extant awards:

(m) South African Defence Force Good Service Medal

New ribbons instituted 1986:

- Gold Medal

- Silver Medal

- Bronze Medal (n) Southern Cross Medal

New ribbon instituted 1986.

(o) Pro Merito Medal

New ribbon instituted 1986.

In effect, therefore, a total of 31 new ribbons has been instituted within the South African medal pantheon since 1986. [To this number one should add the ribbon of the National Intelligence Service Civil Medal (1990), which was instituted after the main body of this work had been completed; thus making a total of 32.] Of these, three bear colours which are identical to preceding awards; i.e. items (c) (ribbons of five grades); (d), (f) (ribbons of two grades); (g) (ribbons of four grades); (h) (ribbon of first grade) (gold); (i) (ribbon of second grade (silver)).

It should, however, be noted that the widths of these ribbons differ from those of their predecessors. Hence, with regard to the Order of the Star of South Africa (Military) and Order of the Star of South Africa (Non-Military) both instituted in 1988, the width of the ribbon is standardised at $36 \mathrm{~mm}$ (for both neck and breast ribbons) and at $20 \mathrm{~mm}$ for miniature ribbons. This regulation differs from the widths prescribed for the ribbons of the order as instituted in 1977/1978 (44 cm for the breast ribbon and $37 \mathrm{~mm}$ for the neck ribbon within both the Military and Non-Military Divisions; and $18 \mathrm{~mm}$ for the miniature ribbon within both divisions). Similarly, the re-constituted Order of Good Hope standardises the neck and breast ribbons at a width of $36 \mathrm{~mm}$, in contrast to the 1973 version, in which the neck ribbons for the First Class (Grand Cross), Second Class (Grand Officer), Third Class (Commander) and Fourth Class (Officer) is stipulated as being 101 $\mathrm{mm}$ for the First Class and $40 \mathrm{~mm}$ for the Second-Fourth Classes. Only the ribbons of the National Intelligence Service Cross for Valour Gold and National Intelligence Service Medal for Distinguished Service - Silver remain unaltered.

Thus, 30 new ribbons must be added to an updated ribbon guide. The revision of the ribbon guide originally produced in 1986 thus embodies a threefold amendment:

(i) Those instituted for completely new additions to the South African/South West African medal pantheon; i.e. items (a), (b), (h), (i), (j). (k);

(ii) Those instituted for extant awards, bearing a different design from their predecessors; i.e. items $(m),(n),(0)$; 
(iii) Those bearing the same design as their predecessors, but of different widths; i.e. item (c) (first four grades), (d), (f), (h), cited in terms of new Warrants.

The restless, fluctuating character of the South African award structure naturally generates profound inhibitions with regard to detailing any summary or overall analysis of its salient features. Nevertheless, it was considered that, in the course of researching and compiling the three previous works, certain central characteristics had emerged as being implicit in the nation's medal pantheon. It was thus decided to incorporate an overall analysis into the final work, which is thus sub-titled, With an overview of the South African award structure.

(b) The question of the ribbon chart introduces the second major divergence from the original work authored by J.P.I. Fforde and S. Monick. Col Fforde had conceived of his chart in strictly chronological sequence. However, it was felt that the finalised ribbon chart to accompany the fourth work in the series (South African civil awards 1910-1990) should follow the pattern of the preceding two publications, which had polarised, so to speak, the award structure in terms of instituting bodies (i.e. armed forces, uniformed public services). The chart is thus divided under the headings of Military awards, South African/South West African uniformed public services and civil awards. It was considered that such an approach would follow the development of Col Fforde's researches on the part of the Museum.

\section{CONCLUSION}

A most noteworthy feature of the research project discussed above is the manner in which the intrinsic and extrinsic facets are closely interwoven. In other words, the innate character of the material researched determined the external processes; e.g. staggered pattern of publication, the revision of the ribbon chart and expanded summaries contained within the fourth and final publication in the series, South African civil awards 1910-1990. The relationship between what might be termed the internal and external characteristics of the projects is rooted, fundamentally, in the restless and fluctuating character of the South African medal pantheon, as has been discussed in detail above. Whilst such aspects persist, it would appear to be impossible to encapsulate such an award structure within a published source, with any degree of finality. The researcher is compelled to pursue the changing features of such a pantheon through the medium of continual revisions, appendices, etc. in relation to earlier published works.

1. The term "pantheon" has been inspired by the concept of the pantheon of Gods in Graeco/ Roman mythology. The essential underlying motif of such a framework is the principle of hierarchy and subordination; a fundamental element in award structures, which are characterised by an order of precedence, implicit within which is the subordination of certain awards to others, in terms of prestige.

* Dr Stanley Monick is the curator of medals and numismatics of the South African National Museum of Military History

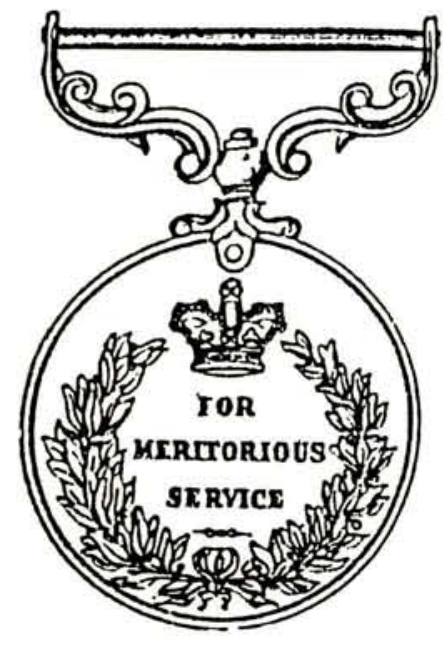

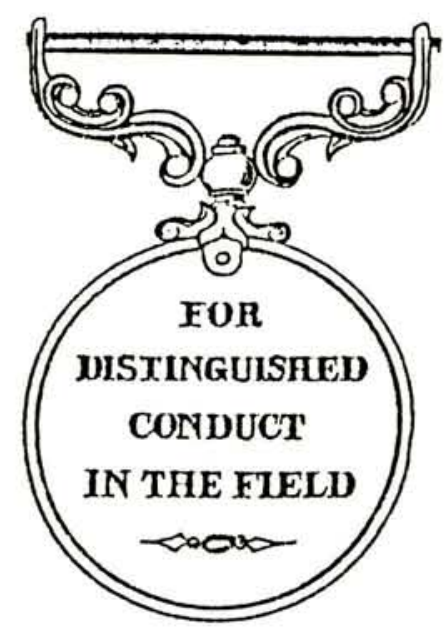

2 


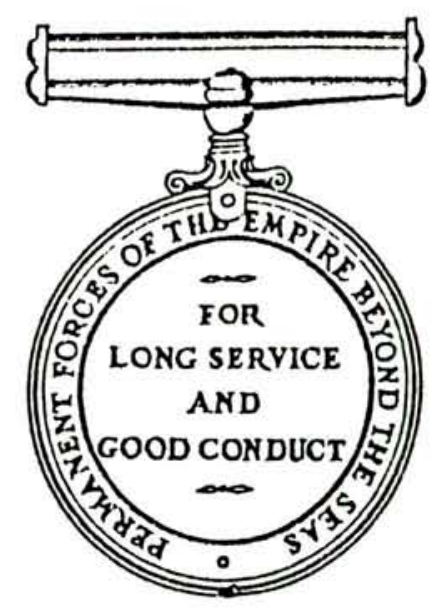

3
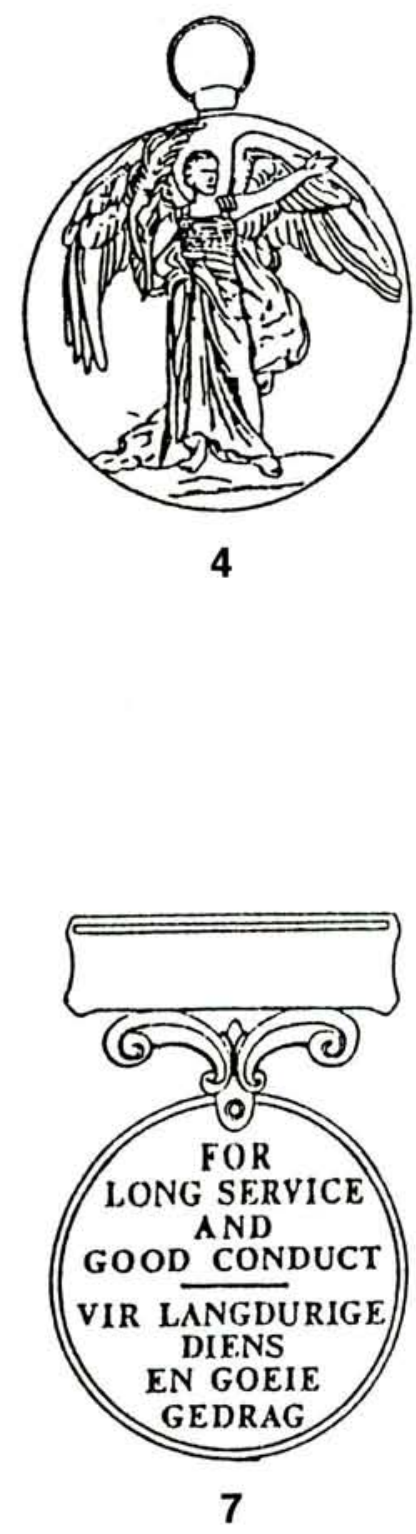

6

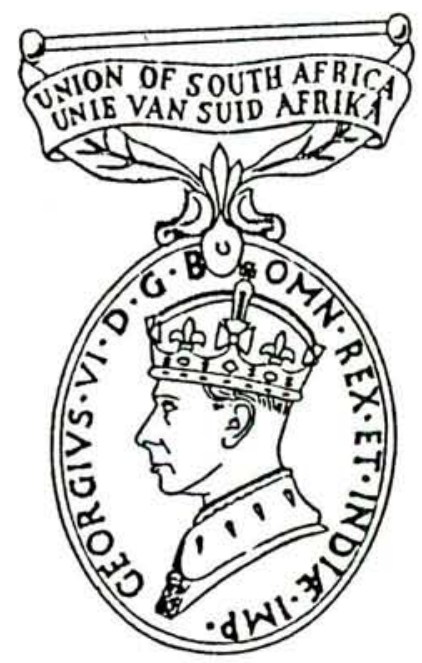

9

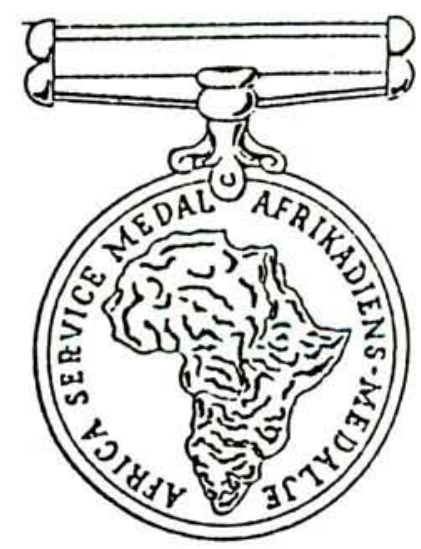

10
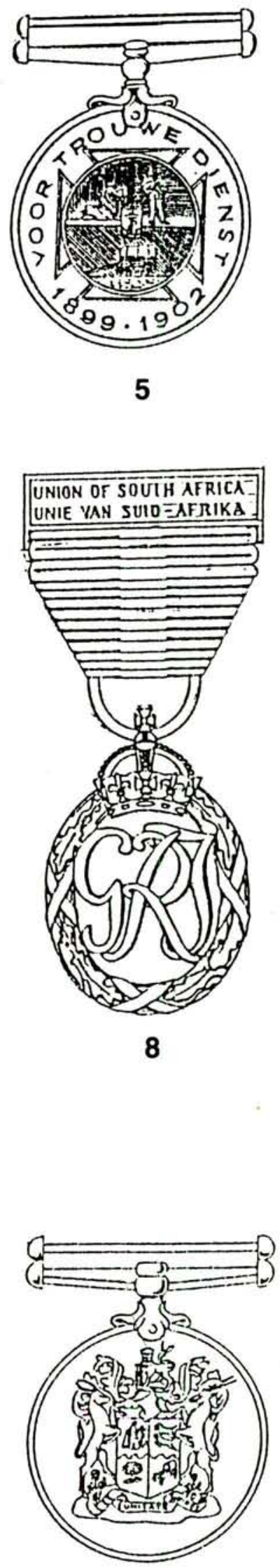

11 


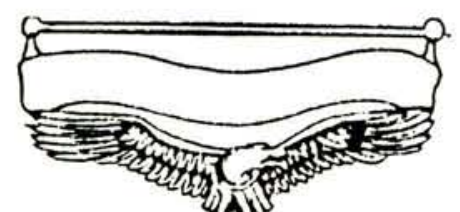

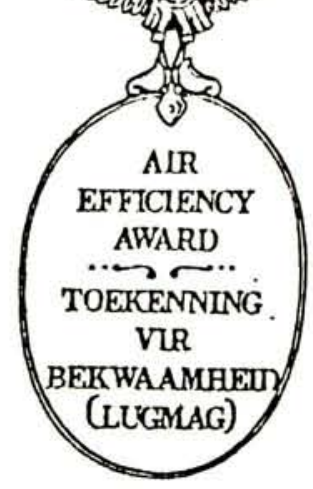

12

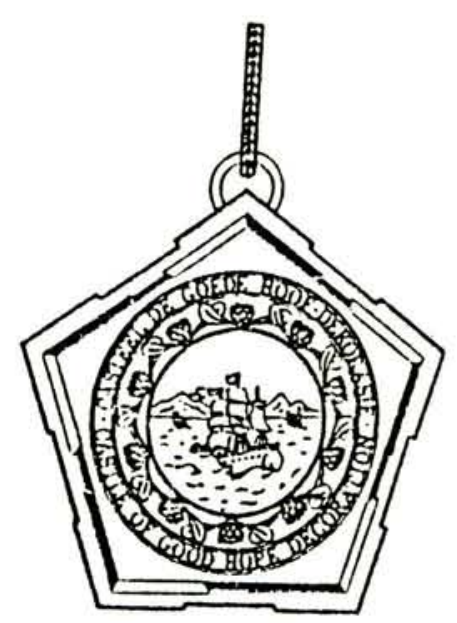

13

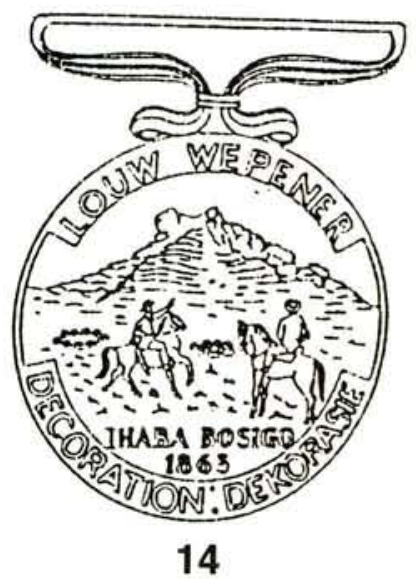

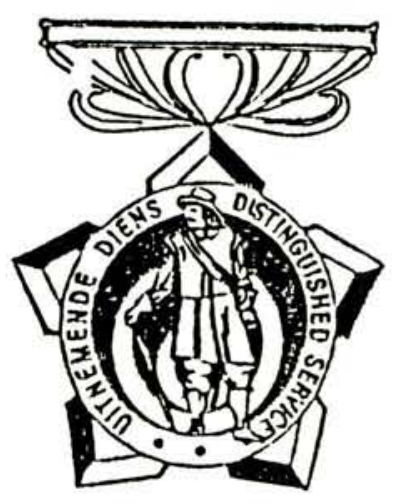

16

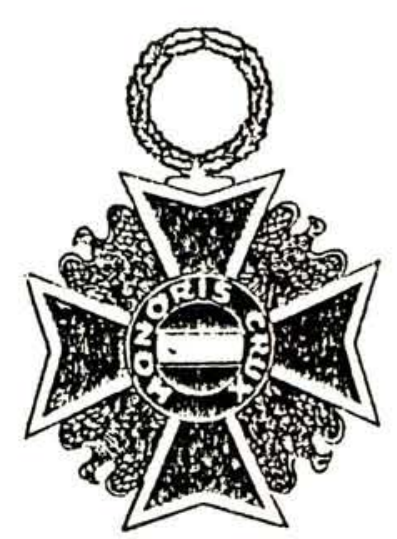

17

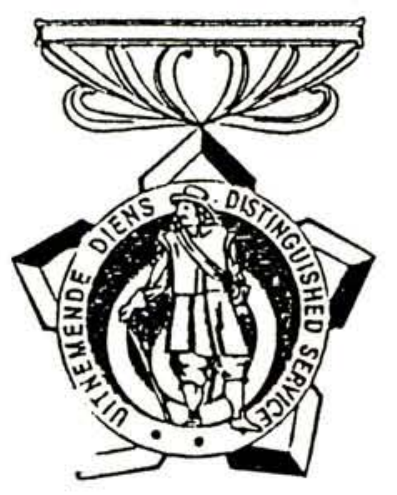

18

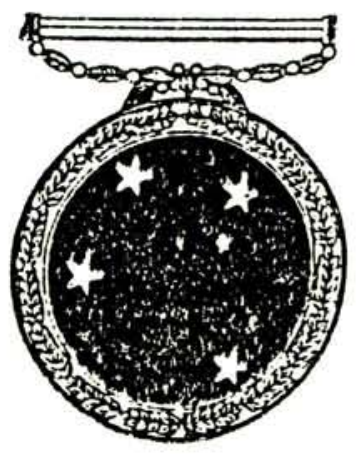

19

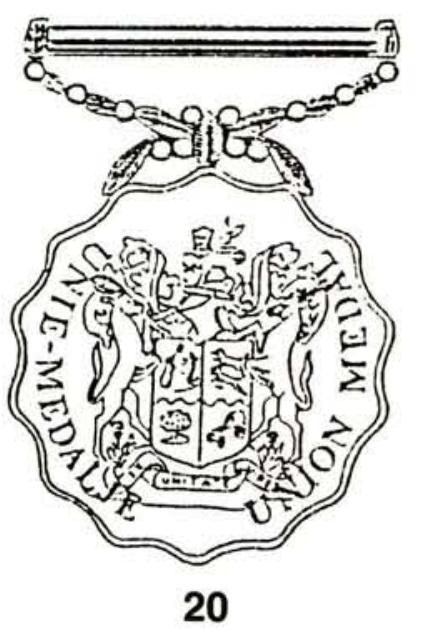




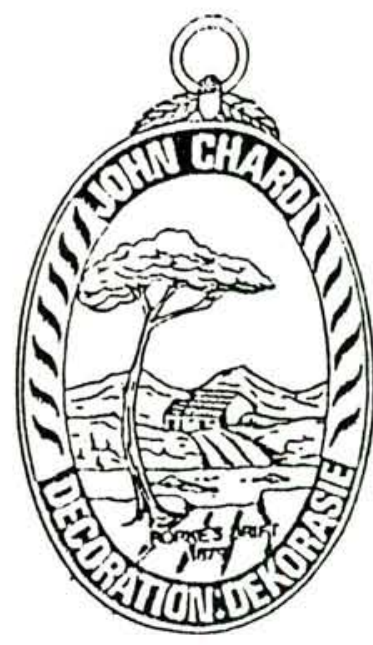

21

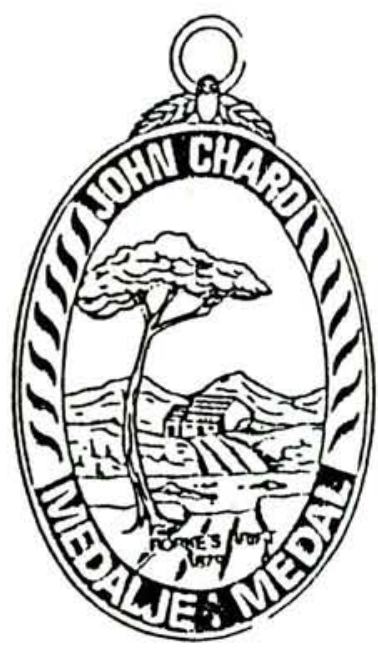

22
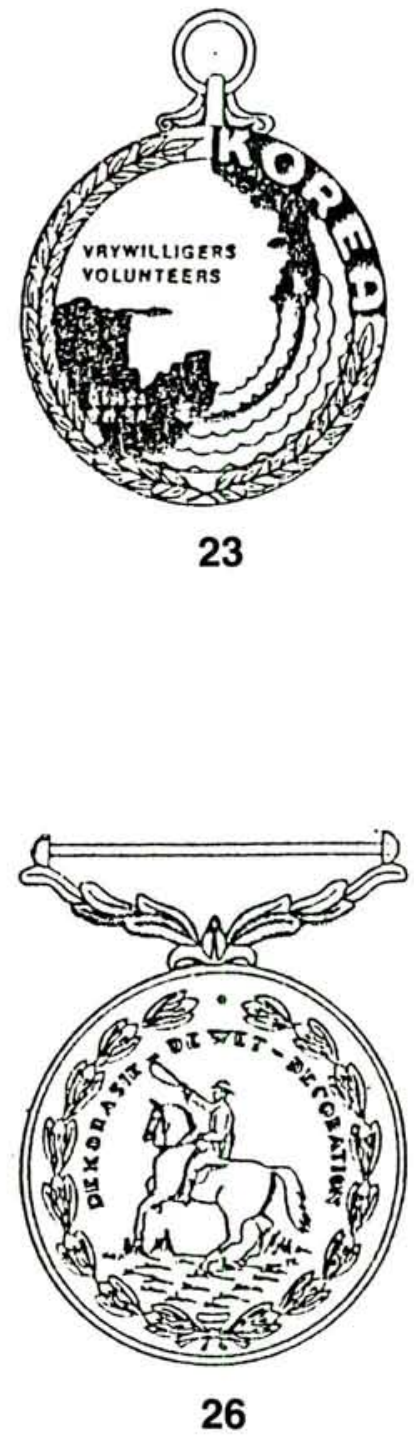

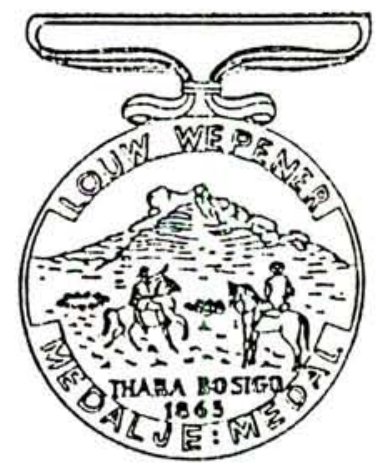

29
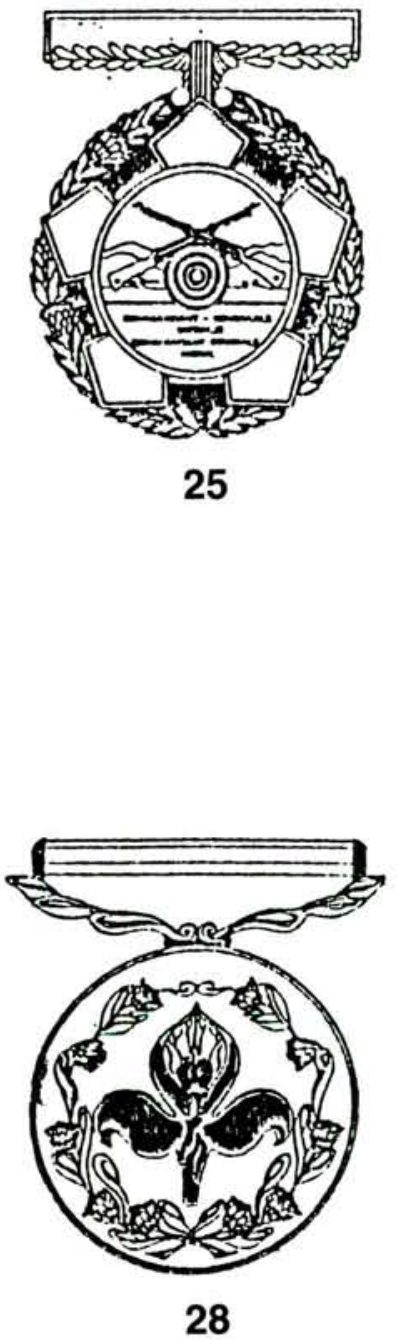


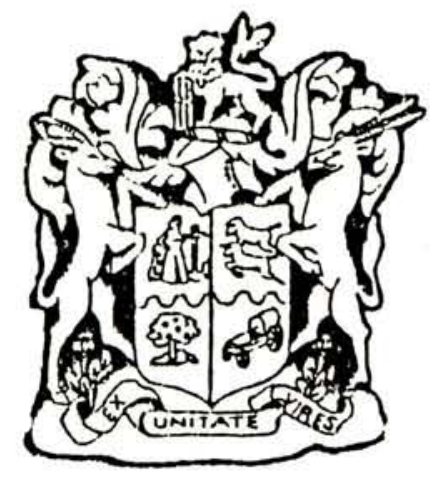

30

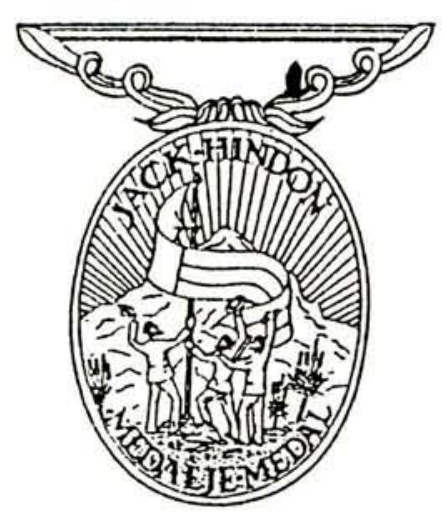

33

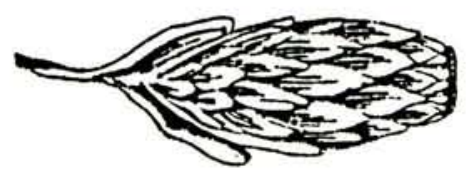

31

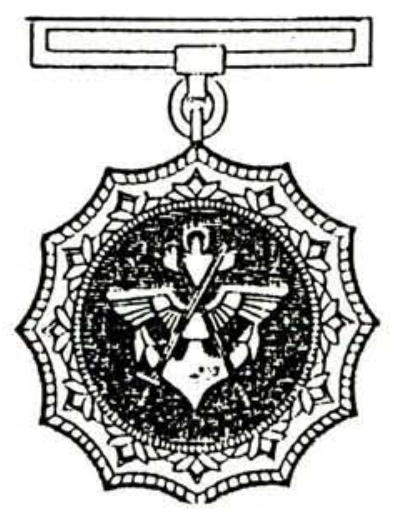

34
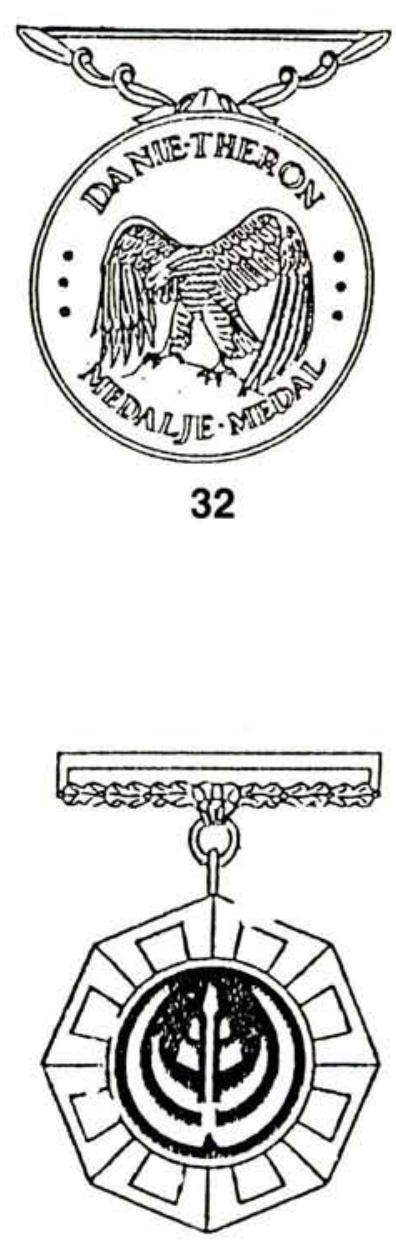

35

Q

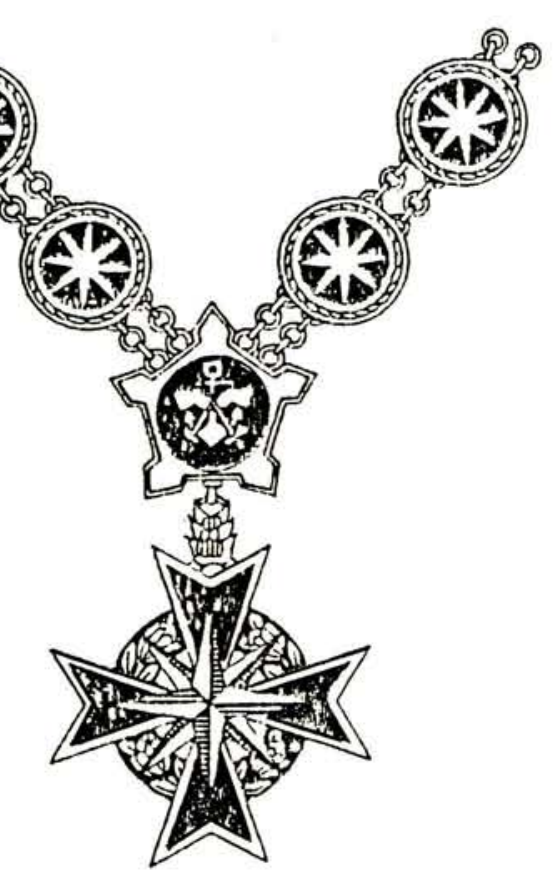

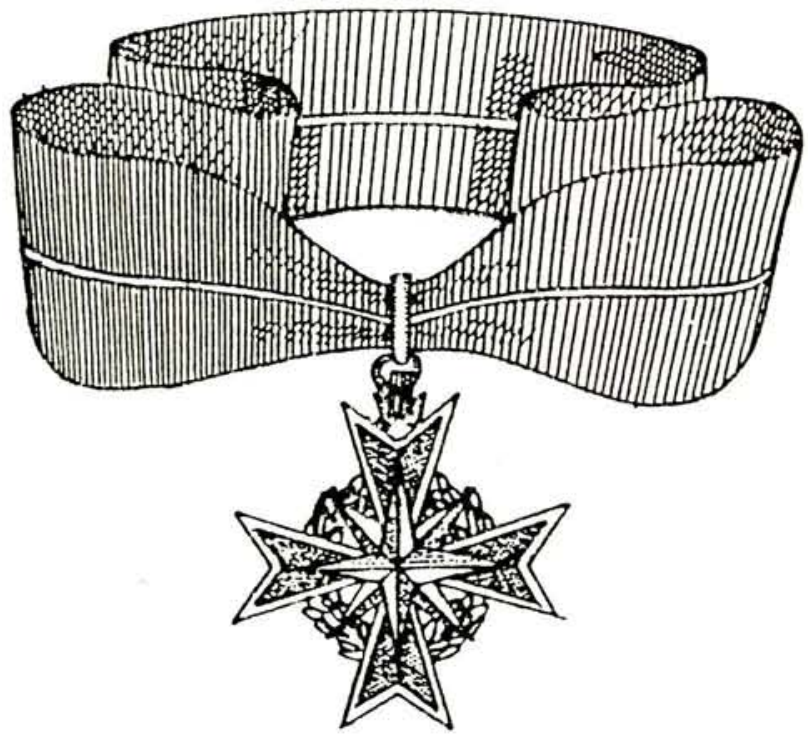

37 

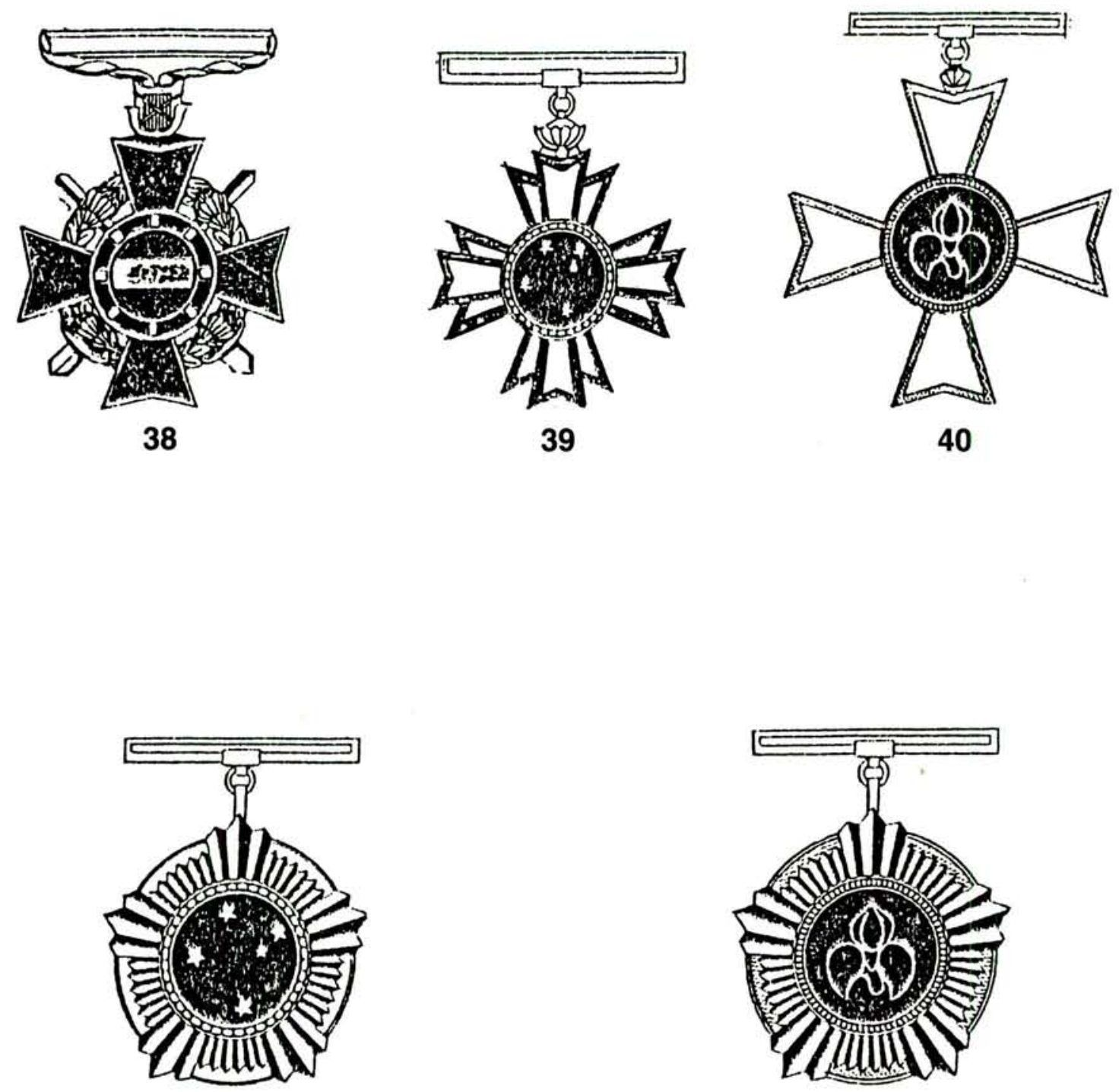

41

42
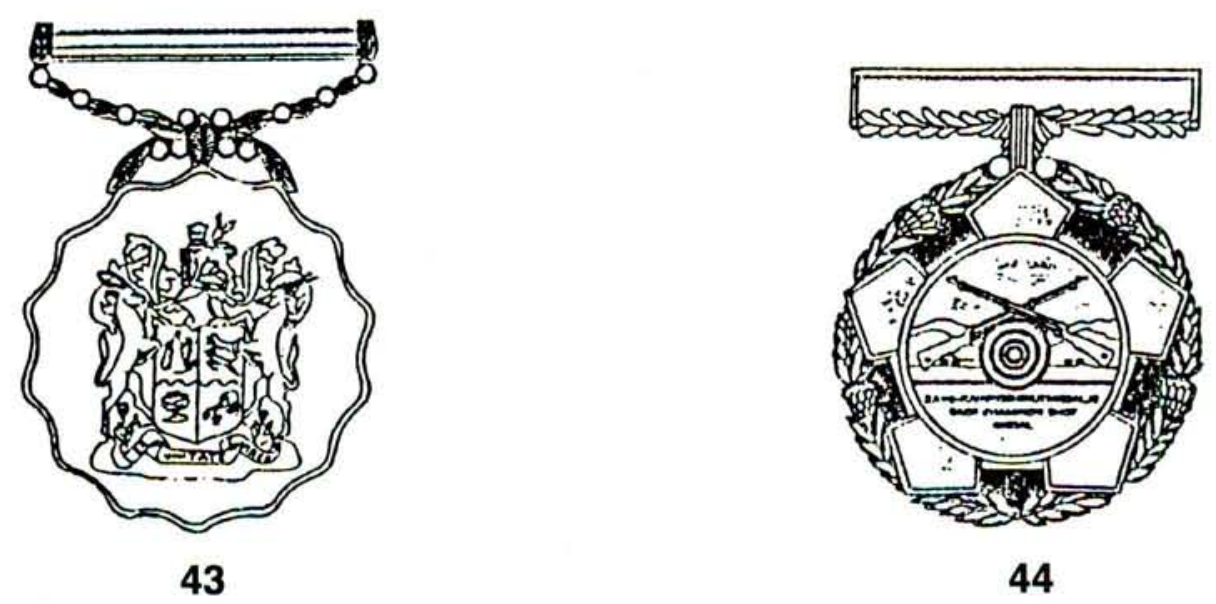


\section{Appendix}

\section{KEY TO ILLUSTRATIONS OF SOUTH AFRI- CAN MILTTARY AWARDS}

1. Meritorious Service Medal (1913)

2. Distinguished Conduct Medal (1913)

3. Long Service and Good Conduct Medal (Permanent Forces of the Empire Beyond the Seas Long Service and Good Conduct Medal) (1913)

4. Allied Victory Medal 1914-1918 (SA issue) (1919)

5. Dekoratie voor Trouwe Dienst 1899-1902 (1920)

6. Anglo-Boere Oorlog Medalje 1899-1902 (1920)

7. Medal for Long Service and Good Conduct (Military) (1939)

8. Efficiency Decoration (1939)

9. Efficiency Medal (1939)

10. Africa Service Medal (initially instituted 1943) (1945)

11. South African Medal for War Services (1945)

2. Air Efficiency Award (1950)

3. Castle of Good Hope Decoration (1952) (instituted 1954)*

4. Louw Wepener Decoration (1952) (instituted 1954)*

5. Star of South Africa (1952) (instituted 1954)*.

6. Van Riebeeck Decoration (1952) (instituted 1954) ${ }^{\star}$

7. Honoris Crux (1952) (instituted 1954)*

8. Van Riebeeck Medal (1952) (instituted 1954)*

9. Southern Cross Medal (1952) (instituted 1954)*

0. Union Medal (1952) (instituted 1954)*

1. John Chard Decoration (1952) (instituted 1954)*

2. John Chard Medal (1952) instituted 1954)*

3. Korea Medal (1953)

4. Permanent Force Good Service Medal (1961)

5. Commandant General's Medal (1965)

6. De Wet Decoration (1965)

7. Cadet Corps Medal (1966)

8. Pro Merito Medal (1967)

9. Louw Wepener Medal (1967)

0 . Mention in Despatches Emblem (1967)

1. Commandant General of the South African Defence Force Commendation Emblem (1967)
32. Danie Theron Medal (1970)

33. Jack Hindon Medal (1970)

34. C SADF Commendation Medal (1974)

35. Pro Patria Medal (1974/1976)

36. Order of the Star of South Africa (1975/1977/ 1978) ${ }^{\star}$ Military Division: Class 1 (Order of the Star of South Africa)/Non-military Division: Class 1 (Grand Cross)

37. Order of the Star of South Africa (1975/1977/ 1978)* Military Division: Class 11 (Order of the Star of South Africa Silver)

38. Honoris Crux Decoration (1975)

39. Southern Cross Decoration (1975)

40. Pro Merito Decoration (1975)

41. Southern Cross Medal (1975)

42. Pro Merito Medal (1975)

43. South African Defence Force Good Service Medal (1975) (Gold/Silver/Bronze)

44. SADF Champion Shot Medal (1975)

* Note: In these items marked * the year of institution is based on the publication of the Royal Warrant in the relevant Government Gazette, not on the date of the Royal Warrant.

To the above list, the following awards of the SADF should be added:

45. Order of the Star of South Africa (Military) (1988)

Class I: Gold

Class II: Silver

46. Order of the Star of South Africa (Non-Military) (1988)

Class I: Grand Cross

Class II: Grand Officer

Class III: Commander

Class IV: Officer

Class V: Member

47. General Service Medal (1990)

48. Southern Africa Medal (1990)

Notes:

(i) The classes within item No. 36 are:

Class I: Order of the Star of South Africa

Class II: Order of the Star of South Africa Silver

(ii) The classes within item No. 37 are:

Class I: Grand Cross

Class II: Grand Officer

Class III: Commander

Class IV: Officer

Class V: Knight 


\section{BIBLIOGRAPHY}

Published works relating to South African awards

\section{MONOGRAPHS}

(i) General works

1. Africana Museum (Johannesburg). Military medals of South African interest. Johannesburg: Africana Museum, 1957.

2. Alexander, E.G.M., Barron, G.K.B. \& Bateman, A.J. South African orders, decorations and medals. Cape Town, Pretoria: Human \& Rousseau, 1986.

3. Fforde, J.P. \& Monick, S. A Guide to South African orders, decorations and medals and their ribbons 1896-1985. Johannesburg: South African National Museum of Military History, 1986.

Note. Contains coloured ribbon chart, relating to medals instituted prior to 1986 .

4. Monick. S. Awards of the South African uniformed public services, 1922 - 1987. Johannesburg: South African National Museum of Military History, 1988.

5. Monick, S. South African military awards 1912-1987. Johannesburg: South African National Museum of Military History, 1988.

6. Moorcraft, Paul L. Africa's super-power. Johannesburg: Sygma Books, Collins Vaal, 1981.

Note: Contains double-spread illustrations of SADF awards.

7. South African National War Museum (Johannesburg). Catalogue. Johannesburg: South African National War Museum, 1959.

8. South African orders, decorations and medals: order of precedence. Government Gazette, Vol 22 № 1625 (30 December 1966) and № 1630 (6 January 1967).

9. Union of South Africa, Department of Defence. South African decorations and medals: reprints of Warrants. Pretoria: Department of Defence, 1960.

\section{(ii) Specialised works}

10. Forsyth, D.R. Die Medaljerol: Dekoratie voor Trouwe Dienst, AngloBoere Oorlog: Die Suid Afrikaanse Republiek en Oranje Vrystat Oorlogsmedalje: Lint voor Verwonding opgedaan gedurende die Anglo-Boere Oorlog. Johannesburg: the Author, 1976.

11. Forsyth, D.R. Efficiency Decoration, Union of South Africa: the roll. Johannesburg: the Author, 1987.

12. Forsyth, D.R. King's Commendation, Military Recipients, Union Defence Force. Johannesburg: the Author, 1987.

13. Owen, Colin R. The South African Korea medal roll. Benoni: Chimperie, 1982

14. Van Wyk, A. Honoris Crux. Ons dapperes: our brave. Cape Town: Saayman \& Weber, 1982

\section{(B) PERIODICAL ARTICLES}

(i) General Works

15. Monick, S. The awards of the South African armed forces: an overview and analysis. Armed Forces (SA), June-August, 1988.

Part 1: June 1988, pp 29-32.

Part 2: July 1988, pp 28-34

Part 3: August 1988, p 28.
16. Monick, S. The enigma of medals. Parts 1-4. Armed Forces (SA), April-July, September, 1984.

(ii) Specialised studies

17. Botha, M.A. Tangible testimony. Servamus, April 1989, pp 18-19, $26-28$.

18. Commandant General's Medal. Commando, XXI, April 1970, p. 79.

19. De Villiers, W. A provisional roll: the Decoration for Meritorious Service. Journal of the Military Medal Society of South Africa No 15, November 1979, pp 35-37.

20. Duxbury, G.R. Louw Wepener Medal. Military History Journal, Vol 1 No 1. December 1967, pp 36-37.

21. Fforde, J.P.I. Republic of South Africa: The Commandant General's Medal. Journal of the Orders and Medals Research Society, No. 2, X (131), July 1971, pp 73-74.

22. Forsyth, D.R. King's Police Medal. Journal of the Military Medal Society of South Africa, December 1978, pp. 17-21.

23. Jones, W.H. The new Star of South Africa Order. Journal of the Orders and Medals Research Society, XVIII (I), 1979, pp 26-28.

24. Jones, W.H. South African Police medals 1923-1979. Orders and Medals Research Society Journal, Autumn 1980, pp 168-178.

25. Kelly, H.K. South African decorations and awards. SA Numismatic Journal, No 7, November 1972, pp 277-278. Note: Deals with John Chard Decoration.

26. King. Alfred T. \& Breed, J.A. Medals of the South African Railways Police Force 1934-1986. Orders and Medals, Vol 27 No 3, pp $156-163$.

27. Langenhoven, P. 'n Medalje vir elkeen. Servamus, February 1988, p. 9. Note: Deals with the South African Police Seventy-Fitth Anniversary Commemorative Medal.

28. Mitchell, F.K. The long service medals of the South African armed forces. De Nummis (Journal of the Transvaal Numismatic Society), nd pp 94-119.

29. Mitchell, F.K. \& Tamplin, J.M.A. The Meritorious Service Medal in South Africa 1896-1952. Journal of the Orders and Medals Research Society, XIV (4), 1975, pp 209-219.

30. Monick, S. The long service and good conduct medals of the South African uniformed public services. Association of South African Numismatic Societies, Journal № 2, 1989, pp 18-50.

31. Pamm, A.N. M.S.M. in South Africa 1896-1952. Journal of the Orders and Medals Research Society, XX (3) (1972), Autumn 1981, p 147.

32. Radburn, Arthur. From Golden Eagle to Cross of Honour. Journal of the Military Medal Society of South Africa, № 29, August 1987, pp 21-24. Note: Deals with Honoris Crux (1952).

33. Radburn, Arthur. The Order of the Star of South Africa. Journal of the Military Medal Society of South Africa, No. 23, December 1983, pp 23-26.

34. Radburn, Arthur. Stars for distinguished leadership. Journal of the Military Medal Society of South Africa, No 24, September 1984, pp 27-28.

Note: Deals with South African Police/South African Railways Police Star for Distinguished Leadership.

35. Tamplin, J.M.A. The awards of the South African Prison Services, Orders and Medals, Vol 22 № 1, Spring 1983, pp 22-25. 